\title{
THE CIVIL LAW NATURE OF ELECTRONIC MONEY
}

\author{
Liudmyla Panova', Vitalii Makhinchuk²
}

\begin{abstract}
The purpose of the article is to examine the civil law nature of electronic money. The subject of the research is the features of the civil law nature of electronic money. Methodology. Research methods are chosen based on the object, subject and purpose of the study. The study used general scientific and special methods of legal science. Thus, the analysis and synthesis method as well as the logical method were used to formulate a holistic view on electronic money, their features and legal nature. The logical-semantic method was used to establish the meaning of the concepts "electronic money", "non-cash money", "payment instrument", "electronic payment instrument". The comparative method was used when analyzing scientific categories, definitions and approaches. The legal modeling method was applied to formulate the author's definition of the term "electronic money". Results. The article generalizes scientific views on the civil law nature of electronic money. A distinction has been made between electronic money and currency unit, non-cash money and the right to claim. As the result it has been established that electronic money is the monetary obligation. Practical implication. The study should assist in developing the unified approach to the issue of the civil law nature of electronic money. Value/originality. As the result of the study the author's definition of the concept "electronic money" with regard to its civil law nature has been proposed.
\end{abstract}

Key words: electronic money, civil law nature, currency unit, payment instrument, cash, non-cash money, issuer.

JEL Classification: E42, K19

\section{Introduction}

The current stage of market economy development is characterized, in particular, by the emergence of a large number of new forms and methods of calculations. The development of information technologies plays an important role in this process, many of which are being used extensively both in the banking and trade. At the same time, the demand for such information technology is increasing, as various forms of e-commerce become more and more popular, i.e. the ways of doing business through the Internet or otherwise, which eliminates or minimizes the personal contact of an entrepreneur with contractors and consumers. As a result, a wide range of ways to accept payments for goods, works and services, and to obtain appropriate cash is available to entrepreneurs.

One of the most innovative methods of calculations, which is most widely used and characterized by rapid development, is electronic money. Despite the fact that electronic money emerged in the 1990s, they entered into circulation only in the early 2000s, and the interest in them has been steadily increasing every year since then. Thus, as of 2018, the volume of e-money issued in Ukraine amounted to 83.2 million UAH, the volume of transactions with electronic money exceeded 7 million $\mathrm{UAH}$, and the amount of electronic money on e-wallets reached 62 million UAH (Official site of the National Bank of Ukraine).

Until recently, the procedure for conducting electronic money transactions was virtually unsettled. Thus, the concept of "electronic money" appeared in the legislation of Ukraine only in 2010. Since then, a significant number of legal acts regulating the issue of non-cash payments have been amended. However, despite the legislator's efforts to regulate this type of public relations, there is currently a lack of research on the legal nature of electronic money and the legal regime associated with it. Besides, in order to harmonize national legislation with that of the European Union, the National Bank of Ukraine has proposed to update the procedure for conducting electronic money transactions, which makes such study even more relevant.

\section{Presentation of the main material}

Let us begin our study on a definition of the concept of "electronic money". In particular, paragraphs 7 and 8 of the Directive 2009/110/EC of the European Parliament

\footnotetext{
Corresponding author:

${ }^{1}$ Taras Shevchenko National University of Kyiv, Ukraine.

E-mail: LPanova@i.ua

${ }^{2}$ F.G. Burchak Scientific-Research Institute of Private Law and Business

of National Academy of Law Sciences of Ukraine, Ukraine.

E-mail:makhinchuk@gestors.com.ua
} 
and of the Council dated September 16,2009 (hereinafter referred to as the EU Directive), governing the single market for e-money and the development of this sector, state that it is appropriate to introduce a clear definition of electronic money in order to make it technically neutral. That definition should cover all situations where the payment service provider issues a pre-paid stored value in exchange for funds, which can be used for payment purposes because it is accepted by third persons as a payment. The definition of electronic money should cover electronic money whether it is held on a payment device in the electronic money holder's possession or stored remotely at a server and managed by the electronic money holder through a specific account for electronic money. That definition should be wide enough to avoid hampering technological innovation and to cover not only all the electronic money products available today in the market but also those products which could be developed in the future" (Directive 2009/110/EC of the European Parliament and of the Council dated September 16, 2009).

The Committee on Payments and Settlement Settings (now The Committee on Payment and Market Infrastructures), the international standard setter for payment systems, defines electronic money (e-money) as "value stored electronically in a device such as a chip card or a hard drive in a personal computer" (CPSS, 2003).

In Ukraine, the legal regulation of the issues related to electronic money is carried out in accordance with the Civil Code of Ukraine, the Law of Ukraine "On Payment Systems and Funds Transfer in Ukraine" dated April 05, 2001, the Law of Ukraine "On E-Commerce" dated September 03, 2015, Resolutions of the Board of the National Bank of Ukraine "On Amendments to Certain Regulations of the National Bank of Ukraine on Regulation of Issue and Circulation of Electronic Money" No. 481 dated November 4, 2010, approving the Regulation on Electronic Money, Regulations of the Board of the National Bank of Ukraine "On Transactions with the Use of Electronic Payment Methods" No. 705 dated November 05, 2014.

According to Article 15 of the Law "On Payment Systems and Funds Transfer in Ukraine" (hereinafter referred as to the Law) electronic money is a unit of value stored on an electronic device, accepted as a means of payment by a person other than the person who issues it, and is a monetary obligation of that person, whether in cash or non-cash form of money.

Thus, from the content of the above definition it becomes obvious that electronic money is of dual nature, i. e., on the one hand, it is a means of payment, and, on the other hand, it is an obligation of the issuer, which indicates the presence of a civil legal component in the legal nature of electronic money.

There are several scientific approaches to defining the civil law nature of electronic money, according to which electronic money is: 1) the form of non-cash form of money; 2) monetary obligation of a bank; 3 ) the right to claim; 4) the counterpart for security; 5) the equivalent of money. The third and the fourth approaches are essentially the same, because securities are inherently property rights (Shimon, 2015).

Regarding the recognition of electronic money as the equivalent of money, the following should be noted. According to Article 192 of the Civil Code of Ukraine the legal payment instrument, which is obligatory for acceptance at nominal value throughout Ukraine, is the hryvnia, the currency of Ukraine.

According to part 3.3, Article 3 of the Law the hryvnia as currency is the only legal tender in Ukraine, which is accepted by all physical and legal persons without any restrictions on the territory of Ukraine for carrying out transfers and payments. The National Bank of Ukraine monopolizes the issue of the national currency of Ukraine and organizes cash circulation (Section 2, Part 1, Article 7 of the Law of Ukraine "On the National Bank of Ukraine").

Electronic money is issued in exchange for cash or non-cash money by the banks other than the National Bank of Ukraine, which, prior to their issue, have agreed the rules on the use of electronic money with the National Bank of Ukraine in the manner prescribed by the normative legal act of the National Bank of Ukraine (Article 15 of the Law).

Therefore, as it is stated in the Letter of the National Bank of Ukraine No. 25-112 / 6750 dated June 07, 2013, "electronic money cannot be equated with the status of the currency of Ukraine, since it is issued by the banks and has its limitations on distribution and operations within a limited category of persons... The currency of Ukraine - the hryvnia - is the only legal payment instrument. That is, the payment instrument exists in the form of monetary unit".

Electronic money cannot also be an electronic means of payment, since the laws of Ukraine distinguish between the terms "electronic payment instrument" and "electronic money".

Thus, paragraph 1.14, Article 1 of the Law states that "electronic payment instrument" is the payment tool that provides its holder with the possibility of using payment device to get information about the proper holder of money and initiate their transfer. The payment instrument is the tool of the particular form on paper, electronic, or other data storage device used to initiate transfers. Payment instruments include transfer documents and electronic means of payment (Section 1.31, Article 1 of the Law).

The definition of "electronic money", which we have considered above, is given in Article 15 of the Law.

Therefore, electronic money, as we have defined, is neither a payment instrument nor an electronic payment instrument, since it does not fall under any of the required characteristics. Since the concept of "means of payment" is not enshrined in the legislation 
of Ukraine, K.R. Petrofanova assumes that electronic money should be understood as means of payment to repay monetary obligations, which arise for one reason or another (Petrofanova, 2016).

The second approach to determining the nature of electronic money is that electronic money is a form of non-cash money. However, as we have already defined, the hryvnia as the currency of Ukraine is the only legal tender in Ukraine. The funds also exist in cash (bank notes) or non-cash form (bank accounts). Therefore, non-cash money is a universal means of payment, whereas the circulation of electronic money is limited by a particular payment system.

The issuer of money is exclusively the National Bank of Ukraine, whereas the issue of electronic money is performed by the bank, which, prior to the beginning of their issue, is obliged to agree the rules on using electronic money with the National Bank of Ukraine in the manner established by the regulatory act of the National Bank of Ukraine.

Electronic money issue is realized by providing it to the users or commercial agents in exchange for cash or non-cash money. The issuer is obliged to ensure that the amount of electronic money issued by it does not exceed the amount of cash or non-cash money received from the users and agents (other than replenishment agent) and the amount received by the replenishment agent to be transferred to the issuer (clause 2.2 of the Regulation "On Electronic Money”).

Non-cash money exists in the form of entries on the bank account, while electronic money exists in the form of records on an electronic device - a chip contained in a plastic card or other media, computer memory, etc. used to store electronic money (clause 1.3 of the Regulation "On Electronic Money"). In this case, the amount of electronic money on non-replenishable electronic device should not exceed $4000 \mathrm{UAH}$, and the amount of electronic money on replenishable electronic device should not exceed $14000 \mathrm{UAH}$. In general, the users have the right to use electronic money to make payments using replenishable electronic device, which is available to the user up to $62000 \mathrm{UAH}$ during the calendar year.

The user of electronic money can be a business entity or an individual. A business entity has the right to use electronic money to pay for goods, works and services. An individual user has the right to use electronic money to pay for goods, works and services and to transfer electronic money to other individual users. A business entity has the right to receive electronic money and to present it for repayment only in exchange for non-cash funds. An individual has the right to receive electronic money and to present it for repayment in exchange for cash or non-cash money (Article 15 of the Law).

Besides, electronic money, unlike non-cash money, cannot be the subject of a credit agreement and a deposit agreement. According to Articles 1054, 1058 of the
Civil Code of Ukraine there is a special entity in these relations: a bank or financial institution related to economic entities. According to the rules of electronic money circulation established by the Regulations on Electronic Money, electronic money can be freely transferred only between individuals; business entities have the right to use electronic money only to pay for goods. Consequently, financial institutions do not have the right to carry out appropriate transactions with electronic money for the conclusion of a credit agreement or deposit agreement (Petrofanova, 2017).

According to V.S. Loshchynin (2013), the main difference between electronic money and non-cash money is not the lack of use of bank accounts, but the procedure and the moment of termination of monetary obligations when using them. First, the transfer of electronic funds is always irrevocable; its irrevocability occurs at the moment of using the electronic means of payment, which is equivalent to the inability to withdraw a payment order; secondly, at the same moment the monetary obligation of the payer to the recipient is considered to be fulfilled.

S.I.Shimon (2013), studying the concept of "electronic money", notes that it, by the civil law nature, are similar to the right to claim to the issuing bank on the repayment of electronic money, which in accordance with Articles 15.1, 15.4 of the Law is implemented by exchanging it for cash or non-cash money. But electronic money also differs from the right to claim, and the legal relationship to its use and repayment are inherent in some features of legal relations in the provision of financial services, which in some way unites them with official money. Thus, electronic money can be anonymous and repeatedly used (transmitted several times from one subject to another), excluding in that respect the right of claim, which as a subjective civil right can be exclusively identified. Considering that electronic money is a claim then, as a matter of terminology, it would mean that the user has the "right to claim". But in fact, the user has the right to request the exchange of electronic money for cash or non-cash money. Besides, such an obligation of the bank is due to the fact that the electronic money came into the electronic purse of the user, that is, it became their owner. The obligation of the bank to issue money to the holder of electronic money is not an obligation of a counter property granting, which exists in obligations, in which property right to claim can be the object of legal relations.

The lawmaker itself, like most scholars, supports the view that electronic money is exactly the monetary obligation, which arises on the basis of a civil contract, the agreement of two parties, under which one party - an individual or a business entity, indicated its willingness to exchange cash or non-cash money for electronic money. It is the will of an individual, or an entity, not of the issuer, unlike the issue of the hryvnia as legal payment instrument in Ukraine, the exclusive right 
to the issue of which belongs to the National Bank of Ukraine, is the main condition for the issue of electronic money (Petrofanova, 2016).

Thus, a user, who purchased electronic money in exchange for cash or non-cash money, is the owner of electronic money. From the perspective of civil law, it acts as a creditor in the obligation, in which the user assigns the right to claim to the merchant (the business entity, registered in accordance with the legislation of Ukraine, which accepts electronic money as a means of payment for goods under the contract, concluded with the issuer or settlement agent) against the debtor - the issuing bank (the issuer is a resident bank that issues electronic money and takes on the obligation to pay them off). In this case, the claim is expressed it is through electronic money, that is, there are civil and legal relations, in which there is a classic replacement of the creditor in the obligation, provided for in Article 512 of the Civil Code of Ukraine. The original creditor transfers all the rights in relation to the obligation to the new creditor to the extent and on the conditions existing at the time of transfer of these rights (Petrofanova, 2016).

T. Lisitsa (2012) also believes that electronic money is not cash (either cash or non-cash money). Electronic money transactions are accounted for as debt claims, and therefore, electronic money is an asset in the form of receivables.

D. Savchuk (2013) supports their views on the civil law nature of electronic money. He believes that electronic money is not a settlement in cash, but a liability, although cash and non-cash money by their legal nature can also be considered liability by their legal nature. The first one is unconditional obligation of the National Bank, and the second one is the obligation of banks to the customers.

I.M. Plisko (2014) argues that electronic money is a tool for calculating the electronic payment system's obligations to its customers, and the transfer of electronic money from wallet to wallet between such customers of the payment system is, in fact, the transfer of the right to claim under such obligations.
Based on the views of the aforementioned scientists, we came to the conclusion that electronic money is the monetary obligation of the issuer in electronic form, the accounting of which is carried out on an electronic device (a chip contained in a plastic card or other medium, computer memory etc.).

\section{Conclusion}

At present, the Ukrainian scholars do not have a unified view of the legal nature of electronic money. Some consider it as currency, the others see it as a right to claim to the issuer, a form of non-cash money, a monetary obligation and so on. Having studied various approaches to this issue, we came to the conclusion that electronic money is the monetary obligation of the issuer in electronic form, the accounting of which is carried out on an electronic device (a chip contained in a plastic card or other medium, computer memory etc.).

It should be emphasized that this issue is also debatable in the world. For example, S. Lanskoy (2000) viewed this concept as a unit of account, a means of payment, a monetary document, a debt instrument, and concludes that electronic money is a debt instrument that facilitates the circulation of bank money.

Alan L. Tyree (1999) examines electronic money as an assignment, a negotiable instrument and a contractual obligation, and leans towards the latter, as the legal analysis of payment by liability transfer that makes the most sense and which accords most closely with the practice and expectation of the parties is the contractual obligation analysis.

Finally, it should be noted that the definition of electronic money provided in Ukrainian legislation is in line with Part 2 of Article 2 of the EU Directive, according to which "electronic money" means electronically, including magnetically, stored monetary value as represented by a claim on the issuer, which is issued on receipt of funds for the purpose of making payment transactions and which is accepted by a natural or legal person other than the electronic money issuer.

\section{References:}

Alan L. Tyree (1999). The legal nature of electronic money. 10 JBFLP, 273. Retrieved from: http://www2.austlii.edu.au/ $\sim$ alan/svc-legal.html

CPSS (2003). "A glossary of terms used in payments and settlement systems", Report by the Committee on Payment and Settlement Systems, Bank for International Settlement, Basle. Retrieved from: https://www.bis.org/ cpmi/glossary_030301.pdf

Directive 2009/110/EC of the European Parliament and of the Council of 16 September 2009 on the taking up, pursuit and prudential supervision of the business of electronic money institutions amending Directives 2005/60/EC and 2006/48/EC and repealing Directive 2000/46/EC (Text with EEA relevance). Retrieved from: https://eur-lex.europa.eu/legal-content/EN/TXT/?uri=CELEX\%3A32009L0110

Lisitsa, T. (2012). Elektronni hroshi ta internet-torhivlia [Electronic money and online trading]. Balance sheet, 47, 37-41. (in Ukrainian)

Loshchynin, V. S. (2013). Pravovaya priroda elektronnyih denezhnyih sredstv i struktura pravootnosheniy pri raschetah $s$ ih ispolzovaniem [The legal nature of electronic money and the structure of legal relations in the calculation with their use]. PhD Dissertation. Moscow. (in Russian) 
Official site of the National Bank of Ukraine. Retrieved from: https://old.bank.gov.ua/control/en/publish/ article?art_id=125412\&cat_id=22918283

On Payment Systems and Funds Transfer in Ukraine: Law of Ukraine of April 05, 2001 no. 2346-III. Bulletin of the Verkhovna Rada of Ukraine, 29, 137. (in Ukrainian)

Petrofanova, K. R. (2016). Osoblyvosti pravovoi rehlamentatsii elektronnykh hroshei v Ukraini: tsyvilno-pravovyi aspekt [Features of Legal Regulation of Electronic Money in Ukraine: Civil Aspect]. Theory and Practice of Law, 2. Retrieved from: http://nbuv.gov.ua/UJRN/tipp 2016 26 (in Ukrainian)

Petrofanova, K. R. (2017). Porivnialna kharakterystyka elektronnykh, hotivkovykh ta bezghotivkovykh hroshei [Comparative analyses of electronic, cash and non-cash money]. Problems of Legality, 139, 86-94. (in Ukrainian)

Plisko, I. M. (2014). Osoblyvosti vidobrazhennia v bukhhalterskomu obliku rozrakhunkiv elektronnymy hroshyma [The features of visualization of electronic money payments in accounting]. Bulletin of the Chernihiv State Technological University. Series: Economic Sciences, 2, 230-235. (in Ukrainian)

Pro elektronni hroshi: postanova Pravlinnia Natsionalnoho banku Ukrainy vid 25 chervnia 2008 r. № 178

[On Electronic Money: Regulation of the Board of the National bank of Ukraine of June 25, 2008 no. 178]. Retrieved from: https://zakon.rada.gov.ua/laws/show/z0688-08 (in Ukrainian)

Pro Natsionalnyi bank Ukrainy: Zakon Ukrainy vid 20 travnia 1999 r. № 679-XIV [On the National Bank of Ukraine: Law of May 20, 1999 no. 679-XIV]. Bulletin of the Verkhovna Rada of Ukraine (BBR), 1999, no. 29, Art. 238). (in Ukrainian)

Savchuk, D. (2013). Elektronni hroshi - ne hroshi? [Electronic money - not money?]. Retrieved from: http://www.kyivpost.ua /opinion/op-ed/electronic-groshi-ne-groshi-35984.html (in Ukrainian)

Serge Lanskoy (2000). The legal nature of electronic money. Revista de Análisis del BCB, 3(2), 97-119.

Shchodo vyznachennia okremykh poniat: lyst Natsionalnoho banku Ukrainy vid 07.06.2013 r. № 25-112/6750

[Concerning the definition of certain concepts: the Letter of the National Bank of Ukraine dated of June 07, 2013 no. 25-112/6750]. Official site of the Verkhovna Rada of Ukraine. Retrieved from: http://law3.rada.gov.ua/laws/ show/v6750500-13 (in Ukrainian)

Shimon, S. (2015). Elektronni hroshi: forma hroshei chy mainovi prava vymohy? [Electronic money: a form of money or property rights claims?]. Legal Ukraine, 9, 36-41. (in Ukrainian)

Shimon, S. (2013). O grazhdansko-pravovoy prirode elektronnyih deneg [On the civil law nature of electronic money]. Science. Society. State, 3(3). Retrieved from: https://cyberleninka.ru/article/n/o-grazhdansko-pravovoyprirode-elektronnyh-deneg/viewer (in Russian)

Tsyvilnyi kodeks Ukrainy: Zakon Ukrainy vid 16 sichnia 2003 r. № 435-IV [Civil Code of Ukraine: Law of Ukraine of January 16, 2003 no. 435-IV]. Bulletin of the Verkhovna Rada of Ukraine, 40-44, 356. (in Ukrainian) 